\title{
Autoimmune hemolytic anemia and autoantibodies in a patient with Plasmodium falciparum infection: report of a rare case and review of the literature
}

\author{
Supat Chamnanchanunt ${ }^{1, *}$, Pravinwan Thungthong2 ${ }^{2}$, Sirvicha Kudsood ${ }^{3}$, Waraporn Somwong ${ }^{4}$, \\ Manassamon Hirunmassuwan ${ }^{5}$
}

\begin{abstract}
Background: Anemia is a common problem among patients with malaria infection, which induces hemolysis during treatment. A few patients present with autoimmune hemolytic anemia (AIHA) and autoantibodies, such as autoanti-E and autoanti-I, during malaria infection.

Objective: To report the clinical response of a patient with Plasmodium falciparum malaria infection with a hemolytic condition.

Methods: We reviewed medical records of a patient with P. falciparum malaria and related literature.

Results: Our patient presented with P. falciparum malaria infection and received artesunate and ceftriaxone to cover potential tropical infectious diseases. After malaria parasite was eradicated, her hemoglobin declined, and AIHA and autoantibodies were found, explaining the cause of anemia. Corticosteroid was given at a standard dosage, and her hemoglobin became normal within 1 week.

Conclusion: Patients with falciparum malaria and both AIHA and autoantibody complications are rare. Our patient responded to malaria eradication and corticosteroid treatment. Most cases reported seem to respond to corticosteroid with a variety of recovery times. However, corticosteroids might increase the severity of infection; more clinical data to support a standard regimen to treat properly rare hematologic complications (AIHA and autoantibodies) in malaria patients are warranted.
\end{abstract}

Keywords: autoimmune hemolytic anemia, autoanti-E, autoanti-I, malaria, steroid

Plasmodium falciparum infection is classified as a severe type of malaria. Anemia is one of the most common complications among patients with malaria infection. The malaria parasite needs to grow and mature in red blood cells (RBCs), which finally leads to hemolysis [1]. The other mechanisms are clearance in spleen and dyserythropoiesis in bone marrow. There

*Correspondence to: Supat Chamnanchanunt, Department of Clinical Tropical Medicine, Faculty of Tropical Medicine, Mahidol University, Bangkok 10400, Thailand, e-mail: supat.cha@mahidol.ac.th

'Department of Clinical Tropical Medicine, Faculty of Tropical Medicine, Mahidol University, Bangkok 10400, Thailand 2Department of Medicine, Rajavithi Hospital, Bangkok 10400, Thailand

${ }^{3}$ Department of Tropical Hygiene, Faculty of Tropical Medicine, Mahidol University, Bangkok 10400, Thailand

${ }^{4}$ Hospital for Tropical Diseases, Faculty of Tropical Medicine, Mahidol University, Bangkok 10400, Thailand

${ }^{5}$ Chulabhorn Hospital, Bangkok 10210, Thailand

¿ Open Access. @ 2017 Supat Chamnanchanunt et al., published by Sciendo. (⿶) BY-Nc-ND This work is licensed under the Creative Commons Attribution NonCommercial-NoDerivatives 4.0 License. 
is a case report of malaria concomitant with hemolytic anemia that might be related to malaria parasite or medication [2]. Drug-induced hemolytic anemia (DIHA) occurs either while the patient is receiving antimalaria treatment or because the parasite modified RBC membranes [2-4].

Autoimmune hemolytic anemia (AIHA) is a process of the destruction of RBCs by anti-RBC autoantibodies. It is difficult to give a definite diagnosis and specific treatment for this condition. Especially, AIHA is a rare disease, which occurs at the same time as the infection $[5,6]$. To our knowledge, there are only 4 case reports of malaria-induced AIHA. All cases were in children, and there was 1 young patient $[2-4,7]$. Until now, there have been few cases of combined AIHA and identifiable autoantibodies in malaria patients. We also have inadequate data for using steroid (immunosuppressive medication) during malaria treatment. Our present case was in an adult patient with $P$. falciparum infection who had AIHA with blood groupspecific autoantibodies. We show the clinical course after receiving steroid treatment.

\section{Case report}

A 43-year-old woman was admitted to hospital with highgrade fever for a week, chills and rigor, and vomiting, and then developing drowsiness. There was no history of orthopnea, paroxysmal nocturnal dyspnea, chest pain, syncope, or apparent bleeding. The patient had traveled to Myanmar and lived in a forest for 3 days. She was nonhypertensive and nondiabetic. Examination revealed pallor, icteric sclera, pulse rate of 114 beats/min, blood pressure of $90 / 56 \mathrm{mmHg}$, and body temperature of $38.3^{\circ} \mathrm{C}$. Chest and cardiovascular system were normal. Abdominal examination showed palpable liver (liver span $14 \mathrm{~cm}$ ) and no splenomegaly. Physical examination of central nervous system function was unremarkable. Blood investigations revealed the following: hemoglobin $11.6 \mathrm{~g} /$ dL, white blood cell (WBC) count 9,000 cells $/ \mathrm{mm}^{3}$, platelet count 105,000 cells $/ \mathrm{mm}^{3}$, blood sugar $80 \mathrm{mg} / \mathrm{dL}$, total bilirubin $6.6 \mathrm{mg} / \mathrm{dL}$, direct bilirubin $6.3 \mathrm{mg} / \mathrm{dL}$, aspartate transaminase $382 \mathrm{U} / \mathrm{L}$, alanine transaminase $210 \mathrm{U} / \mathrm{L}$, total protein $5.3 \mathrm{~g} / \mathrm{dL}$, albumin $2.6 \mathrm{~g} / \mathrm{dL}$, blood urea nitrogen $64.4 \mathrm{mg} / \mathrm{dL}$ (normal range 6-20 mg/dL), and serum creatinine $2.66 \mathrm{mg} / \mathrm{dL}$ (normal range $0.510-0.95 \mathrm{mg} / \mathrm{dL}$ ). Peripheral blood smears showed normochromic and microspherocytic red cells, agglutination of RBCs, normal leukocytes, and malaria parasite (5-ring stage of $P$. falciparum malaria per 1,000 RBCs on the thin blood smear and a ring stage with 1 gametocytic stage of P. falciparum malaria per $200 \mathrm{WBCs}$ on a thick blood smear) (Figure 1). Chest X-ray image was unremarkable. An indirect immunofluorescent test of serum for rickettsia infections (scrub typhus and murine typhus) was negative. The patient was diagnosed with severe malaria infection ( $P$. falciparum) and treated with a recommended dose of artesunate $(2.4 \mathrm{mg} /$ $\mathrm{kg}$ bodyweight per dose intravenous [i.v.]) for 5 days and combined with ceftriaxone ( $2 \mathrm{~g} /$ day i.v.) for 10 days. All blood cultures were negative (Figure 2). She developed defervesce and completely eradicated the malaria parasite from her blood within 4 days of receiving antimalaria therapy. Her hemoglobin gradually decreased from $9.2 \mathrm{~g} / \mathrm{dL}$ (on the fourth day after starting treatment) to $3.5 \mathrm{~g} / \mathrm{dL}$ (on the 12th day after starting treatment) (Figure 2). A stool test for occult blood was negative. We requested that she have a RBC transfusion, but could not find compatible blood. A direct antiglobulin test (DAT) showed a positive result (DAT showed $2+$ anti-IgG and anti-C3), but an indirect antiglobulin test was negative. A cold agglutinin test was not available in our case. Her blood group was B and Rh positive. Her blood film was compatible with hemolysis (Figure 1). Laboratory findings of hemolysis were indirect hyperbilirubinemia (total bilirubin $=1.6 \mathrm{mg}$ / $\mathrm{dL}$; normal 0-1.2 mg/dL), reticulocytosis (reticulocyte count $=6.6 \%$; normal $0.5 \%-2.5 \%)$, and lactate dehydrogenase $(\mathrm{LDH})$ level of 3,040 U/L (normal 240-480). Antinuclear antigen (ANA) and anti-dsDNA tests were negative. Therefore, a diagnosis of severe malaria infection concomitant with AIHA was considered. To treat her severe anemia, compatible blood was not available because of positive screening for antibody. We sent her blood for further testing to identify the specificity of the antibody according to the British Committee for Standards in Haematology (BCSH) guidelines [8]. A tube and microcolumn agglutination test to identify the antibody demonstrated autoanti-E and autoanti-I.

She received steroid (prednisolone) at $1 \mathrm{mg} / \mathrm{kg}$ bodyweight daily and supportive medication (omeprazole $20 \mathrm{mg}$ / day). Three days later, her blood was matched with 1 unit of leukocyte-poor packed RBCs, and no transfusion reaction occurred during transfusion. The patient showed marked improvement on the steroid treatment after 1 week. Her hemoglobin level became normal within 2 weeks. The patient was discharged on a tapering course of the steroid as an outpatient within a month. Her hemoglobin had increased to $13.9 \mathrm{~g} / \mathrm{dL}$ within normal limits of peripheral blood smear, and a blood test for the malaria parasite found none after 1 month (Figures 1 and 2). The patient was tested again to identify the autoantibody and was found negative for specific antibody using the tube and microcolumn agglutination test in the fourth month following the treatment for the malaria infection.

The present case report was approved by the Ethical Committee of Rajavithi Hospital (approval No. 229/2559). The patient has provided her written consent for the publication of this case report and any accompanying information and images. 

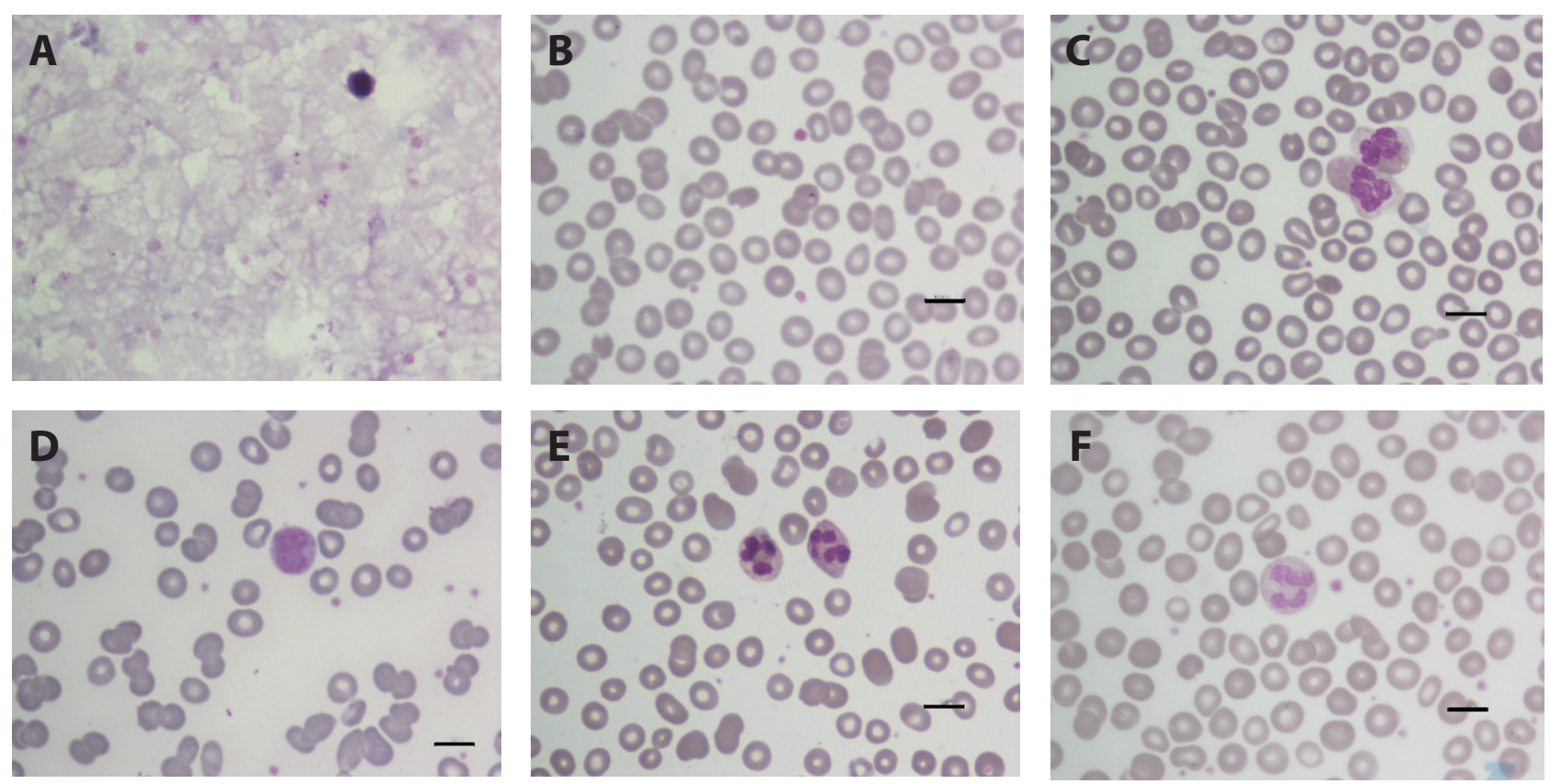

Figure 1. (A and B) Both thick and thin blood films showing a ring form of Plasmodium falciparum parasite with normal finding of red blood cells (RBCs) on the first day of admission. (C) Peripheral blood film from the fourth day after antimalaria treatment. The RBCs, leukocytes, and platelets are normal. (D) Peripheral blood film showing RBCs with autoagglutination and microspherocytosis. (E) On the fifth day after steroid treatment, some clumping of RBCs is seen on peripheral blood film. (F) Peripheral blood film showing RBCs, leukocytes, and platelets are normal at the second week after steroid treatment. All scale bars indicate $10 \mu \mathrm{m}$.

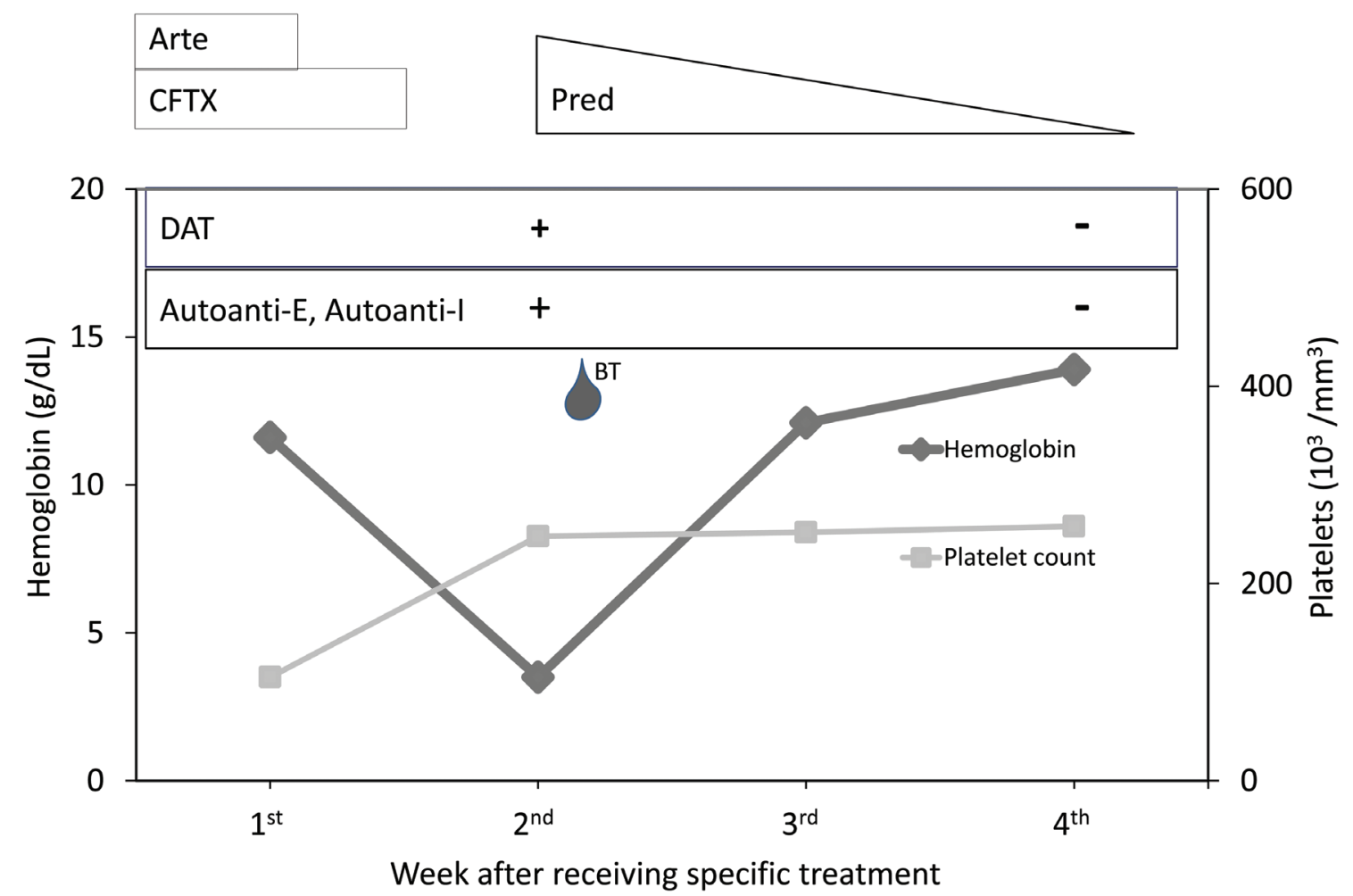

Figure 2. Evolution of autoimmune hemolytic anemia and development of autoantibodies during severe Plasmodium falciparum malaria infection treated with intravenous artesunate.

+ , positive; -, negative Arte, artesunate; BT, blood transfusion; CFTX, ceftriaxone; DAT, direct antiglobulin test;

Pred, prednisolone 


\section{Discussion}

AIHA concomitant with malaria infection is a rare condition. AHIA can be classified on the basis of the temperature suitable for detecting autoantibody binding to RBC membranes into warm antibody (WA-AIHA), cold antibody (CA-AIHA), and biphasic antibody. This condition can be primary or secondary to lymphoproliferative disorders, autoimmune disorders, or hematological malignancy $[9,10]$. Tropical infectious diseases related to AIHA are rare conditions and cause problems. History and clinical findings include pallor, dyspnea, jaundice, and laboratory investigations that are essential for demonstrating hemolysis conditions (high reticulocytosis, indirect hyperbilirubinemia, and LDH).

Our patient underwent clinical and laboratory investigations of her hemolytic condition during treatment for malaria. Her condition was compatible with severe falciparum infection because of renal impairment, algid malaria, and severe anemia [11]. Treatment of algid malaria was with the combination artesunate as an i.v. infusion and the rapid eradication of malaria parasite with a broad-spectrum antibiotic [11]. Afterward, her blood smear developed microspherocytes and clumping of RBCs, which were consistent with AIHA. The RBCs from this patient tested positive for DAT (positive for anti-IgG antisera). The majority of reported cases have been in young patients and children, which is contrary to our experience of a case in an adult patient. The predominant sex affected is female among the case reports. There was one patient with an autoimmune disorder (tested positive for ANA) [4]. The patient with an autoimmune disorder was investigated for the cause of warm-type AIHA (such as medication, autoimmune disorders, and lymphoproliferative disorders). For most patients with malaria, AIHA occurs during the second week after receiving treatment for malaria [2, 4, 7].

The blood of the present patient was screened and found positive for antibodies. We rechecked her history and found that she had neither a history of previous blood transfusion nor pregnancy. A blood sample was referred to a RBC reference laboratory of the Thai Red Cross Society according to BCSH guidelines [12]. The results revealed both autoanti-E and autoanti-I on RBCs. For her severe anemia symptoms, RBC transfusion with E-antigen-negative blood was indicated. We found no transfusion reaction for this compatible blood type. To our knowledge, our patient has the first reported case of a combination of AIHA and autoanti-E with autoanti-I in a malaria patient, and we postulate that these conditions were induced by $P$. falciparum infection or treatment. There are two reports of isolated autoanti-E in infectious patients, which may be related to modified RBC membranes and effects of anti-parasite phospholipid antibodies [13, 14]. For anti-I, there is one incidental finding reported in a child with $P$. vivax malaria infection [7]. To our knowledge, the present case is the first in which multiple blood group specific autoantibodies were identified in an adult patient with malaria, who had neither previous blood transfusion nor pregnancy. Malaria $P$. falciparum-infected erythrocytes can modify not only the cytoplasm, but also the outer membrane of RBCs (loss of antigens CD-55 and CD-59) [4, 15]. Artesunate-related hemolysis is a potential cause of AIHA (DIHA) in patients with malaria, and is related to delayed immune-mediated hemolysis [3]. To our knowledge, only 1 study has demonstrated that ceftriaxone is related to DIHA, but not related to the production of autoantibodies [16]. Two medications (artesunate and ceftriaxone) might have induced DIHA in our present patient. These medications are rarely used in the general population, and patients can self-recover from DIHA by discontinuing the suspected medication.

Specific treatments in this study and from the literature are summarized in Table 1. Most of the malaria patients with AIHA received an immunosuppressive drug (steroid) in either i.v. or oral form $[3,4,7]$. Our patient received an oral form of prednisolone at a recommended dose [10, 17], and her hemoglobin level returned to normal within 1 week. This recovery period is similar to that found by Nayak et al. [2], Raffray et al. [3], and Sitcharungsi et al. [7], who reported recovery ranging from 4 to 10 days. However, Nayak et al. [2] reported selfrecovery without any specific treatment for AIHA. The dosage of prednisolone for AIHA was $1 \mathrm{mg} / \mathrm{kg} /$ day to start tapering off to none when the hemoglobin level returned normal without the evidence of hemolysis [4, 7, 10]. All patients with reviewed cases showed a good clinical recovery without any complications from malaria or AIHA treatment.

Thus, we recommended a short course of a standard dose of oral prednisolone treatment for severe anemic malaria with the evidence of AIHA. However, predicting factors for AIHA and autoantibodies in patients with malaria infection remain unclear and require more data to elucidate.

Author contributions. SC and PT substantially contributed to the conception and case design. SC, PT, and SK acquired the case data. SC, PT, WS, and MH analyzed and interpreted it. All the authors substantially contributed to drafting and critically revising the manuscript, approved the final version submitted, and take responsibility for statements made in the published article.

Acknowledgments. The authors thank Ms. Lertnapa Lertlum and Ms. Supasri Keawpia for preparing the patient's blood 
Table 1. Summary of patients with malaria concomitant with autoimmune hemolytic anemia

\begin{tabular}{|c|c|c|c|c|c|c|c|}
\hline $\begin{array}{l}\text { Reference/ } \\
\text { Characteristic }\end{array}$ & $\begin{array}{l}\text { Present } \\
\text { case }(2016)\end{array}$ & [2] & [3] & [4] & & & [7] \\
\hline Age (years) & 42 & 27 & 17 & 15 & 7 & 15 & 7 \\
\hline Sex & Female & Male & Female & Female & Female & Female & Male \\
\hline Presenting symptom & $\begin{array}{l}\text { Fever } \\
\text { (7 days) }\end{array}$ & $\begin{array}{l}\text { Fever } \\
\text { ( } 2 \text { days) }\end{array}$ & $\begin{array}{l}\text { Fever } \\
\text { (7 days) }\end{array}$ & $\begin{array}{l}\text { Fever } \\
\text { (4 days) }\end{array}$ & $\begin{array}{l}\text { Fever } \\
\text { (7 days) }\end{array}$ & $\begin{array}{l}\text { Fever } \\
\text { (14 days) }\end{array}$ & $\begin{array}{l}\text { Fever } \\
\text { (3 days) }\end{array}$ \\
\hline Malaria infection & P.f. & P.f. & P.f. & P.v. + P.f. & P.v. + P.f. & P.f. & P.v. \\
\hline $\begin{array}{l}\text { Anti-malarial } \\
\text { regimen (duration) }\end{array}$ & $\begin{array}{l}\text { Artesunate } \\
\text { i.v. (7 days) }\end{array}$ & $\begin{array}{l}\text { Antimalarial } \\
\text { treatment } \\
\text { (unknown) }\end{array}$ & $\begin{array}{l}\text { Artemether/lumefantrine } \\
\text { ( } 6 \text { days) and then artesunate } \\
\text { ( } 2 \text { days) }\end{array}$ & $\begin{array}{l}\text { Artesunate i.v. } \\
\text { (5 days) }\end{array}$ & $\begin{array}{l}\text { Artesunate } \\
\text { i.v. ( } 5 \text { days })+ \\
\text { mefloquine }\end{array}$ & $\begin{array}{l}\text { Artesunate i.v } \\
\text { (N/A) }\end{array}$ & $\begin{array}{l}\text { Chloroquine } \\
\text { ( } 2 \text { days })+ \text { prima- } \\
\text { quine ( } 14 \text { days) }\end{array}$ \\
\hline $\begin{array}{l}\text { Other antibiotic } \\
\text { treatment }\end{array}$ & Ceftriaxone & $\mathrm{N} / \mathrm{A}$ & $\begin{array}{l}\text { Ceftriaxone, metronidazole, } \\
\text { gentamicin, piperacillin, } \\
\text { ciprofloxacin }\end{array}$ & $\begin{array}{l}\text { Ceftriaxone, } \\
\text { doxycycline }\end{array}$ & Ceftriaxone & Ceftriaxone & NEG \\
\hline $\begin{array}{l}\text { Onset of AlHA (days } \\
\text { after antimalarial } \\
\text { treatment) }\end{array}$ & 12th & $1 s t$ & 14th & 9 th & 7 th & 11 th & 2nd \\
\hline \multicolumn{8}{|l|}{ Diagnostic method } \\
\hline $\begin{array}{l}\text { Hemoglobin } \\
(\mathrm{g} / \mathrm{dL})\end{array}$ & 3.5 & Hct. $15.2 \%$ & 4.6 & 4.8 & 5.1 & 4.5 & 5.2 \\
\hline Coombs test & POS & NEG & POS & NEG & $\mathrm{N} / \mathrm{A}$ & NEG & POS \\
\hline $\mathrm{LDH}(\mathrm{U} / \mathrm{L})$ & High & $\mathrm{N} / \mathrm{A}$ & High & High & High & High & $\mathrm{N} / \mathrm{A}$ \\
\hline \multicolumn{8}{|l|}{ Identify cause } \\
\hline ANA & NEG & $\begin{array}{l}\text { N/A } \\
\text { CA test POS }\end{array}$ & NEG & $\begin{array}{l}\text { NEG } \\
\text { CA test POS }\end{array}$ & POS & NEG & $\mathrm{N} / \mathrm{A}$ \\
\hline $\begin{array}{l}\text { Antibody } \\
\text { identification }\end{array}$ & $\begin{array}{l}\text { Autoanti-E } \\
\text { Autoanti-I }\end{array}$ & $\mathrm{N} / \mathrm{A}$ & $\mathrm{N} / \mathrm{A}$ & $\mathrm{N} / \mathrm{A}$ & N/A & $\mathrm{N} / \mathrm{A}$ & Autoanti-I \\
\hline $\begin{array}{l}\text { Specific treatment } \\
\text { for AlHA (dosage) }\end{array}$ & $\begin{array}{l}\text { Predni- } \\
\text { solone } \\
\text { (1 MKD) }\end{array}$ & No & $\begin{array}{l}\text { Methylprednisolone } \\
(60 \mathrm{mg} / \text { day } \times 7 \text { days }) \\
\text { Prednisolone ( } 1 \mathrm{MKD})\end{array}$ & $\begin{array}{l}\text { Prednisolone } \\
\text { (1 MKD) }\end{array}$ & $\begin{array}{l}\text { Prednisolone } \\
(\mathrm{N} / \mathrm{A})\end{array}$ & $\begin{array}{l}\text { Prednisolone } \\
(0.5 \mathrm{MKD})\end{array}$ & $\begin{array}{l}\text { Prednisolone } \\
\text { (1 MKD) }\end{array}$ \\
\hline $\begin{array}{l}\text { PRC transfusion } \\
\text { (unit) } \\
\text { Duration of recovery }\end{array}$ & 1 & 0 & 0 & 2 & 3 & 0 & 1 \\
\hline $\begin{array}{l}\text { Malaria infection } \\
\text { (days) }\end{array}$ & 5 & $\mathrm{~N} / \mathrm{A}$ & $\mathrm{N} / \mathrm{A}$ & $\mathrm{N} / \mathrm{A}$ & 7 & 11 & 2 \\
\hline AlHA, anemia (days) & 8 & 4 & 7 & 28 & 28 & 56 & 10 \\
\hline $\begin{array}{l}\text { Stop prednisolone } \\
\text { (days) }\end{array}$ & 30 & $\mathrm{~N} / \mathrm{A}$ & 60 & 42 & 28 & $\mathrm{~N} / \mathrm{A}$ & 56 \\
\hline
\end{tabular}

AIHA, autoimmune hemolytic anemia; ANA, antinuclear antigen; CA, cold agglutinin; Hct., hematocrit; i.v., intravenously; LDH, lactate dehydrogenase; MKD, milligram per kilogram per day; N/A, no data available; NEG, negative; P.f., Plasmodium falciparum; PRC, packed red blood cells; POS, positive; P.v., Plasmodium vivax

smear slides and Miss Chanjira Sae-Lim and Miss Boongong Noochan for imaging the digital files for publication. This study was supported by the Prasert Prasarttong - Osoth Research Foundation, which is operated by the Medical Association of Thailand and a research grant from the Thai Society of Haematology.

Conflict of interest statement. The authors have each completed and submitted an ICMJE Uniform Disclosure Form for Potential Conflicts of Interest. None of the authors disclose any potential conflict of interest.

\section{References}

[1] Perkins DJ, Were T, Davenport GC, Kempaiah P, Hittner JB, Ong'echa JM. Severe malarial anemia: innate immunity and pathogenesis. Int J Biol Sci. 2011; 7:1427-42.

[2] Nayak D, Belurkar SV, Manohar C, Shashikiran U. Cold agglutinins associated with Plasmodium falciparum malaria: a case report. Int J Sci Res. 2014; 4:1-3.

[3] Raffray L, Receveur M-C, Beguet M, Lauroua P, Pistone T, Malvy D. Severe delayed autoimmune haemolytic anaemia following artesunate administration in severe malaria: a case report. Malar J. 2014; 13:398. doi:10.1186/1475-2875-13-398. 


\section{IIlli ASIAN BIOMEDICINE}

[4] Sharma V, Samant R, Hegde A, Bhaja K. Autoimmune hemolysis in malaria: a report of three cases. J Assoc Physicians India. 2012; 60:129-30.

[5] Shizuma T. [A case of autoimmune hemolytic anemia caused by type A influenza infection in a patient with alcoholic liver cirrhosis]. Kansenshogaku Zasshi [J Jap Assoc Inf Dis]. 2010; 84:296-9. (in Japanese, English abstract)

[6] Montagnani S, Tuccori M, Lombardo G, Testi A, Mantarro S, Ruggiero E, Blandizzi C. Autoimmune hemolytic anemia following MF59-adjuvanted influenza vaccine administration: a report of two cases. Ann Pharmacother. 2011; 45:e8. doi:10.1345/aph.1P480

[7] Sitcharungsi R, Anurathapan U, Sirachainan N, Chanthavanich P. Auto-immune haemolytic anaemia concurrent with Plasmodium vivax infection: a case report. Ann Trop Paediatr. 2011; 31:87-91.

[8] Milkins C, Berryman J, Cantwell C, Elliott C, Haggas R, Jones J, et al.; British Committee for Standards in Haematology. Guidelines for pre-transfusion compatibility procedures in blood transfusion laboratories. Transfus Med. 2013; 23:3-35.

[9] Chaudhary R, Das SS. Autoimmune hemolytic anemia: from lab to bedside. Asian J Transfus Sci. 2014; 8:5-12.

[10] Zanella A, Barcellini W. Treatment of autoimmune hemolytic anemias. Haematologica. 2014; 99:1547-54.
[11] Lalloo DG, Shingadia D, Bell DJ, Beeching NJ, Whitty CJM, Chiodini PL, for the PHE Advisory Committee on Malaria Prevention in UK Travellers. UK malaria treatment guidelines 2016. J Infect. 2016; 72:635-49.

[12] Chapman JF, Elliott C, Knowles SM, Milkins CE, Poole GD, for the Working Party of the British Committee for Standards in Haematology Blood Transfusion Task Force. Guidelines for compatibility procedures in blood transfusion laboratories. Transfus Med. 2004; 14:59-73.

[13] Gomes LR, Martins YC, Ferreira-da-Cruz MF, Daniel-Ribeiro CT. Autoimmunity, phospholipid-reacting antibodies and malaria immunity. Lupus. 2014; 23:1295-8.

[14] Daniel-Ribeiro CT. Is there a role for autoimmunity in immune protection against malaria? Mem Inst Oswaldo Cruz. 2000; 95:199-207.

[15] Butcher G. Autoimmunity and malaria. Trends Parasitol. 2008; 24:291-2.

[16] Guleria VS, Sharma N, Amitabh S, Nair V. Ceftriaxone-induced hemolysis. Indian J Pharmacol. 2013; 45:530-1.

[17] Go RS, Winters JL, Kay NE. How I treat autoimmune hemolytic anemia. Blood. 2017; 129:2971-9. 